\author{
Paweł Piepiora1 ${ }^{1}$, Klaudia Kaśków \\ University School of Physical Education in Wrocław, Faculty of Sport Sciences
}

\title{
Personality profile of Polish Volleyball players - a case study of players at various sports levels
}

\begin{abstract}
Aim. The aim of the study was to check if there are differences in the personality of volleyball players in Poland at different levels of sports advancement. Method and subject. The study was conducted with the NEO-FFI Personality Inventory on three groups of Polish volleyball players: first league $(n=30)$, second league $(n=30)$, third league $(n=30)$.

Results. First league volleyballers showed lower levels of neuroticism and higher extraversion and conscientiousness indicators than players from the third league. Conclusions. There are statistical significant differences between volleyballers at different sports levels in the scales of neuroticism, extraversion and conscientiousness.
\end{abstract}

Keywords: sport psychology, personality, NEO-FFI, volleyball, sports level

\section{Introduction}

The psychology of sport has existed almost from the beginning of the psychological sciences. The first documentation of the research in this field is ascribed to the 19th century. In addition, personality studies on which all the work focuses were the first to be subjected to frequent observations in the field of sport psychology. This is because personality plays a key role in the athlete's profession (FEPSAC, 2015). In many works, researchers considered the answer to the question of what personality is important for given disciplines. In others, they were looking for traits that are responsible for success or failure. Attempts have been made to determine what impact a discipline may have on personality. In psychology, we may have contact with many personality ideas, while a perfect pattern is sought. It should also be borne in mind that the sport they represent is also of great importance in determining the personality profile. From analyzing literature, it can be concluded that there is a great need to study personality traits in athletes and there is little data on athletes from given disciplines at different levels of advancement (Piepiora, 2015, 2019; Piepiora, Piepiora, 2015; Piepiora, Witkowski, 2018; Piepiora i in., 2015, 2016a, 2016b, 2017a, 2017b, 2017c, 2017d, 2017e, 2018a, 2018b, 2019a, 2019b, 2019c, 2019d).

\footnotetext{
${ }^{1}$ Paweł Piepiora, e-mail: pawel.piepiora@awf.wroc.pl, ORCID: 0000-0002-6525-3936
} 


\section{Aim, method and subject}

The aim of the study was to check if there are differences in the personality of indoor volleyball players in Poland at different levels of sports advancement. The study used the NEO-FFI personality questionnaire, the so-called "Big five". The test consists of 60 items, which means 12 statements for each of the scales, i.e. neuroticism (NEU), extraversion (EKS), openness to experience (OTW), agreeableness (UGD) and conscientiousness (SUM). The affirmative sentences to which the respondents have to respond have notes from 1 to 5, where: 1 - I strongly disagree, 2 - I disagree, 3 - I have no opinion, 4 - I agree, 5 - I strongly agree. The test results are calculated by adding up the points obtained according to the answer key. Between 0 and 4 points can be awarded for each selected answer. Due to the fact that each of the five scales contains 12 items, the respondent for each of them can receive from 0 to 48 points. The key was created in such a way that the number of points is proportional to the intensification of one of the features. Interpretation of NEO-FFI results covers two levels: psychometric and psychological. This means that the results of the respondent are presented against the background of the appropriate reference group and assume the necessity of estimating the results based on ranges. Then, results that are between 1 and 3 sten are called low, and those between 7 and 10 are high (Wiggins, 1996; McCrae, Costa Jr, 2003; Costa Jr, McCrae, 2007).

The study involved 90 men, 30 volleyball players from the first (PS1), second (PS2) and third (PS3) volleyball league. The first of the examined groups were indoor volleyballers who take part in the first league games in Poland. The age range of the respondents was from 18 to 29 , and the players' education was in the range from medium to higher. This group includes volleyballers from the following clubs: APP Krispol Września, AZS AGH Kraków, Exact System Norwid Częstochowa, KS Gwardia Wrocław, KS Lechia Tomaszów Mazowiecki, MCKiS Jaworzno, MKS Ślepsk Suwałki, STS Olimpia Sulęcin, Tauron AZS Częstochowa, UKS Mickiewicz Kluczbork. The first league is commonly referred to as "Plusliga". This is due to the fact that the team that wins the championship and meets all regulatory requirements will be promoted to the highest rank games in Poland. This is a professional league because the earnings of athletes are the only source of income. Trainings usually take place five times a week, twice a day. First league matches are also broadcast on Polsat TV sports channels.

The other examined group were indoor volleyballers taking part in second league games. The age range of these players ranged from 19 to 34 years old, and education from professional to higher. NEO-FFI was filled by volleyballers from the following clubs: BGS KS "Orzeł" Międzyrzecz, AZS Politechnika Opolska, Czarni Wirex Rząśnia, MKS Ikar Legnica, LUKS Wilki Wilczyn, KS Bielawianka Bester Bielawa, MKST Astra Nowa Sól, MUKS Huragan Wołomin, LUMKS Kasztelan Rozsza, NTS Trójka Nakło, Juve Głuchołazy, MKS Olavia Oława, AZS University of Zielona Góra. The second league, unlike the first and Plusliga, has several competition groups. There are 56 teams that divide into 6 groups of nine and ten teams. They are arranged according to the nearest neighboring towns. The league is commonly called "semi-amateur" because players receive a small payment for 
representing the club and this is not the only source of income. Training in the second league usually takes place 3 to 5 times a week, once a day.

The third group that participated in the research were players participating in the third indoor volleyball league games. The age range of these athletes was between 17 and 35 years old, and vocational to higher education. Personality inventories were completed by volleyballers from the following clubs: KS Gwardia Wrocław, TS Faurecia Volley Jelcz Laskowice, SMS Olimp Oborniki Śląskie, Tygrysy Strzelin, UKS SMS Wybicki Kielce, MKS Pogoń Góra, MKS ZAKSA Kędzierzyn-Koźle. Unlike the previously mentioned leagues, each third league team is subject to the relationship of a given province. Only taking first place in the table of a given province will give you a pass to national competitions and the opportunity to fight for promotion to the higher league. The third league is called amateur. Players do not receive any funds and playing is just a pleasure and hobby. Trainings usually take place 3 times a week, once a day.

\section{Results}

\section{$\underline{\text { Neuroticism (NEU) }}$}

Basic descriptive data on the neuroticism scale are summarized in Table 1 and illustrated in Figure 1. A statistically significant difference in the neuroticism scale occurred between the players of the first and third league of indoor volleyball (Table 2).

Tab. 1. A summary of basic descriptive statistics of the variable neuroticism of the three groups of volleyball players under study.

\begin{tabular}{|c|c|c|c|c|c|c|c|}
\hline LEAGUE & $\begin{array}{c}\text { NEU } \\
\text { Average }\end{array}$ & $\begin{array}{c}\text { Trust } \\
\mathbf{- 9 5 , 0 0 \%}\end{array}$ & $\begin{array}{c}\text { Trust } \\
\mathbf{+ 9 5 , 0 0 \%}\end{array}$ & $\begin{array}{c}\text { NEU } \\
\text { Important }\end{array}$ & $\begin{array}{c}\text { NEU } \\
\text { Standard } \\
\text { deviation }\end{array}$ & $\begin{array}{c}\text { NEU } \\
\text { Min }\end{array}$ & $\begin{array}{c}\text { NEU } \\
\text { Maks }\end{array}$ \\
\hline PS1 & 4,066667 & 3,478844 & 4,654489 & 30 & 1,574218 & 1 & 8 \\
\hline PS2 & 4,733333 & 4,068732 & 5,397935 & 30 & 1,779836 & 1 & 8 \\
\hline PS3 & 5,366667 & 4,727511 & 6,005822 & 30 & 1,711691 & 1 & 9 \\
\hline Average & 4,722222 & 4,354689 & 5,089755 & 90 & 1,754787 & 1 & 9 \\
\hline
\end{tabular}




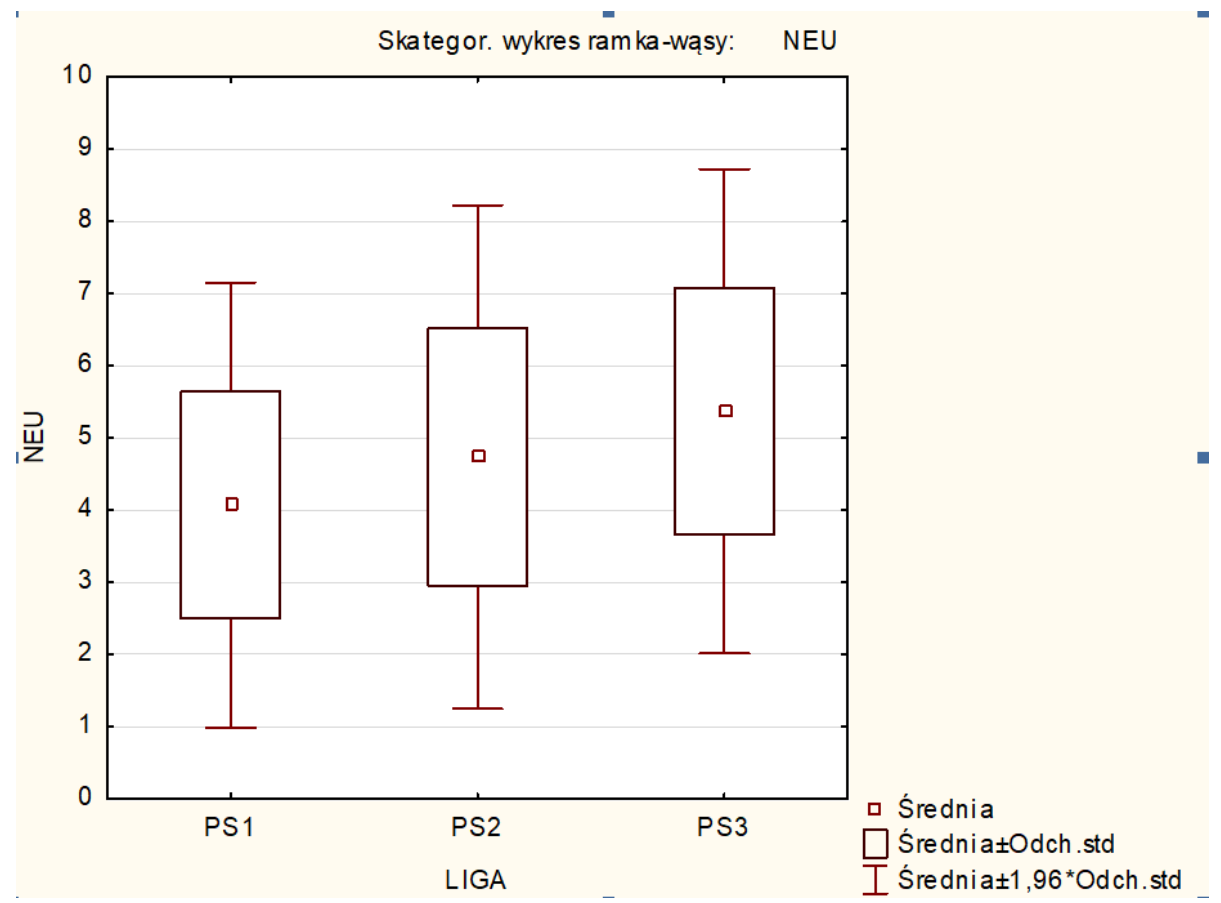

Fig. 1. Graph for the variable neuroticism of the three examined groups of volleyball players.

Tab.2. Summary of the strength of differences in the scale of neuroticism between the studied groups.

\begin{tabular}{|c|c|c|c|}
\hline \multicolumn{4}{|c|}{ Tuckey's RIR test; variable: NEU; Significance at the level $\mathbf{p}<\mathbf{0 , 0 5}$} \\
\hline & $\{\mathbf{1}\}-\mathbf{M}=\mathbf{4 , 0 6 6 7}$ & $\{\mathbf{2}\}-\mathbf{M}=\mathbf{4 , 7 3 3 3}$ & $\{\mathbf{3}\}-\mathbf{M}=\mathbf{5 , 3 6 6 7}$ \\
\hline PS1 $\{\mathbf{1}\}$ & & 0,283398 & 0,010498 \\
\hline PS2 $\{\mathbf{2}\}$ & 0,283398 & & 0,319813 \\
\hline PS3 $\{\mathbf{3}\}$ & 0,010498 & 0,319813 & \\
\hline
\end{tabular}

\section{$\underline{\text { Extroversion (EKS) }}$}

The basic descriptive data on the extraversion scale are summarized in Table 3 and illustrated in Figure 2. A statistically significant difference in the extraversion scale occurred between the players of the first and third league of indoor volleyball (Table 4). 
Tab. 3. Summary of basic descriptive statistics of the extraversion of the three examined groups of volleyball players.

\begin{tabular}{|c|c|c|c|c|c|c|c|}
\hline LEAGUE & $\begin{array}{c}\text { EKS } \\
\text { Average }\end{array}$ & $\begin{array}{c}\text { Trust } \\
\mathbf{- 9 5 , 0 0 \%}\end{array}$ & $\begin{array}{c}\text { Trust } \\
\mathbf{+ 9 5 , 0 0 \%}\end{array}$ & $\begin{array}{c}\text { EKS } \\
\text { Important }\end{array}$ & $\begin{array}{c}\text { EKS } \\
\text { Standard } \\
\text { deviation }\end{array}$ & $\begin{array}{c}\text { EKS } \\
\text { Min }\end{array}$ & EKS Maks \\
\hline PS1 & 6,966667 & 6,210365 & 7,722968 & 30 & 2,025413 & 3 & 10 \\
\hline PS2 & 6,666667 & 5,950529 & 7,382805 & 30 & 1,917853 & 3 & 10 \\
\hline PS3 & 5,9 & 5,491542 & 6,308458 & 30 & 1,09387 & 3 & 8 \\
\hline Average & 6,511111 & 6,140617 & 6,881605 & 90 & 1,768923 & 3 & 10 \\
\hline
\end{tabular}

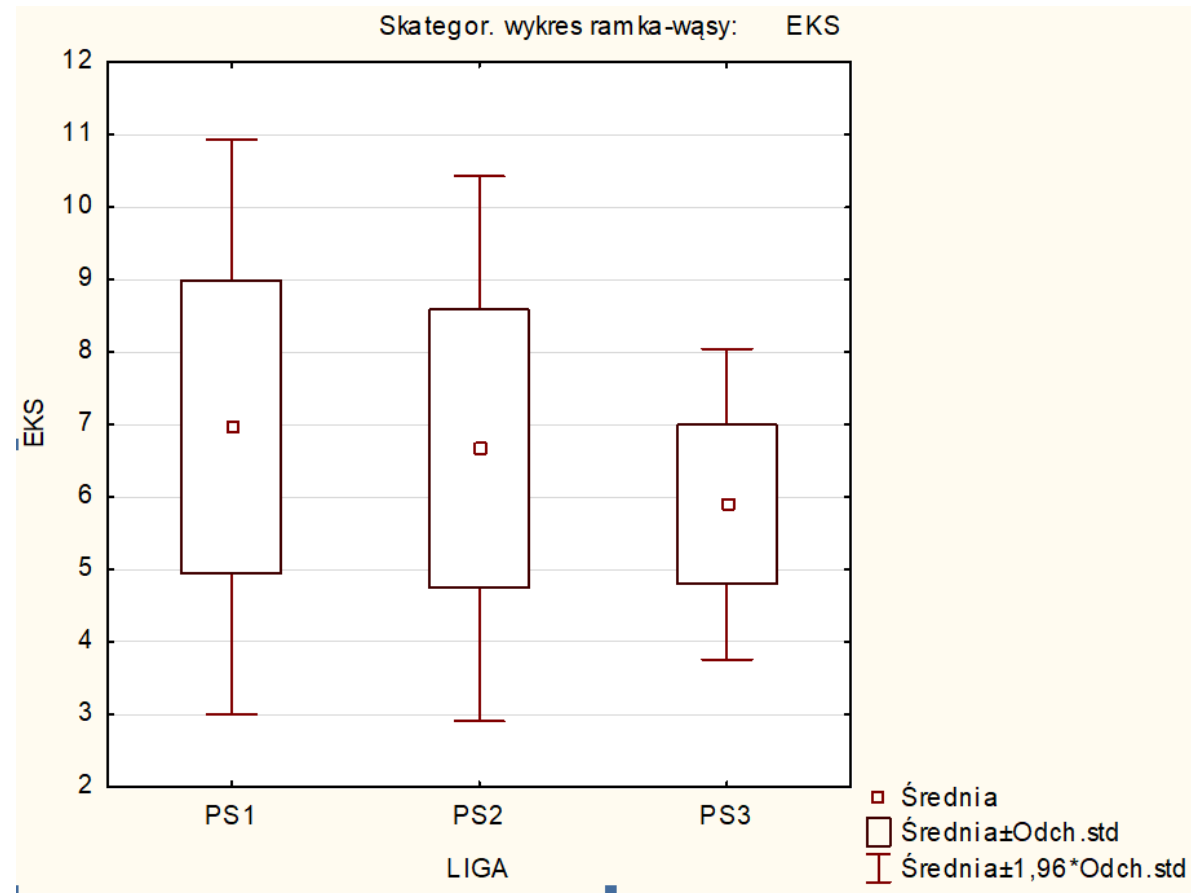

Fig. 2. Graph for the variable extraversion of the three groups of volleyball players under study.

Tab.4. Summary of the strength of differences in extraversion between the studied groups.

\begin{tabular}{|c|c|c|c|}
\hline \multicolumn{4}{|c|}{ Tuckey's RIR test; variable: EKS; Significance at the level $\mathbf{p}<\mathbf{0 , 0 5}$} \\
\hline & $\{\mathbf{1}\}-\mathbf{M}=\mathbf{6 , 9 6 6 7}$ & $\{\mathbf{2}\}-\mathbf{M = 6 , 6 6 6 7}$ & $\{\mathbf{3}\}-\mathbf{M = 5 , 9 0 0 0}$ \\
\hline PS1 $\{\mathbf{1}\}$ & & 0,780612 & 0,049631 \\
\hline PS2 $\{\mathbf{2}\}$ & 0,780612 & & 0,204899 \\
\hline PS3 $\{\mathbf{3}\}$ & 0,049631 & 0,204899 & \\
\hline
\end{tabular}




\section{Openness to experience (OTW)}

Basic descriptive data on the scale of openness to experiments are summarized in Table 5 and illustrated in Figure 3. No statistically significant differences were found on the scale of openness to experiments. Due to the value of $p=0.859$ higher than the accepted significance level of 0.05 given by the program, it was found that in the three leagues examined the average on the scale of openness to experiments was statistically equal. Post-hoc tests were not needed.

Tab. 5. A list of basic descriptive statistics of variable openness to the experiences of the three examined groups of volleyball players.

\begin{tabular}{|c|c|c|c|c|c|c|c|}
\hline LEAGUE & $\begin{array}{c}\text { OTW } \\
\text { Average }\end{array}$ & $\begin{array}{c}\text { Trust } \\
\mathbf{- 9 5 , 0 0 \%}\end{array}$ & $\begin{array}{c}\text { Trust } \\
\mathbf{+ 9 5 , 0 0 \%}\end{array}$ & $\begin{array}{c}\text { OTW } \\
\text { Important }\end{array}$ & $\begin{array}{c}\text { OTW } \\
\text { Standard } \\
\text { deviation }\end{array}$ & $\begin{array}{c}\text { OTW } \\
\text { Min }\end{array}$ & $\begin{array}{c}\text { OTW } \\
\text { Maks }\end{array}$ \\
\hline PS1 & 4,2333 & 3,639408 & 4,827259 & 30 & 1,590561 & 1 & 7 \\
\hline PS2 & 4,1333 & 3,462969 & 4,803698 & 30 & 1,795268 & 1 & 8 \\
\hline PS3 & 4,3666 & 3,790826 & 4,942507 & 30 & 1,542129 & 2 & 9 \\
\hline Average & 4,2444 & 3,902933 & 4,585955 & 90 & 1,630545 & 1 & 9 \\
\hline
\end{tabular}

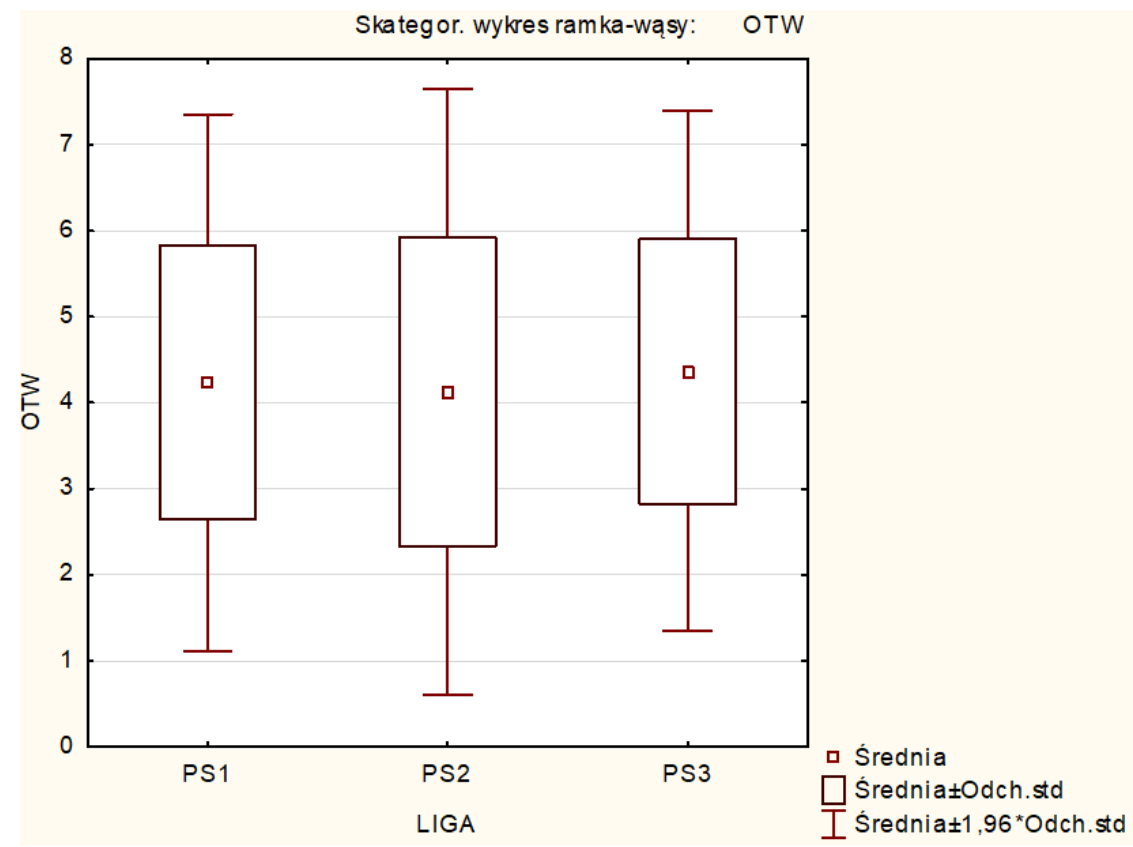

Fig. 3. Graph for variable openness to the experiences of the three examined volleyball groups. 


\section{$\underline{\text { Agreeableness (UGD) }}$}

Basic descriptive data on the agreeableness scale are summarized in Table 6 and illustrated in Figure 4. No statistically significant differences were found on the agreeableness scale. The value of $\mathrm{p}=0.527$ given by the program was greater than the adopted level of significance of 0.05 , it was found that in the three leagues examined the mean in the agreeableness scale was statistically equal. Post-hoc testing was not necessary.

Tab. 6. A list of basic descriptive statistics of the variable agreeableness of the three groups of volleyball players under study.

\begin{tabular}{|c|c|c|c|c|c|c|c|}
\hline LEAGUE & $\begin{array}{c}\text { UGD } \\
\text { Average }\end{array}$ & $\begin{array}{c}\text { Trust } \\
\mathbf{9 5 5 , 0 0 \%}\end{array}$ & $\begin{array}{c}\text { Trust } \\
\mathbf{+ 9 5 , 0 0 \%}\end{array}$ & $\begin{array}{c}\text { UGD } \\
\text { Important }\end{array}$ & $\begin{array}{c}\text { UGD Standard } \\
\text { deviation }\end{array}$ & $\begin{array}{c}\text { UGD } \\
\text { Min }\end{array}$ & $\begin{array}{c}\text { UGD } \\
\text { Maks }\end{array}$ \\
\hline PS1 & 5,666667 & 4,957274 & 6,376059 & 30 & 1,899788 & 2 & 9 \\
\hline PS2 & 5,5 & 4,794572 & 6,205428 & 30 & 1,889171 & 2 & 9 \\
\hline PS3 & 5,133333 & 4,462969 & 5,803698 & 30 & 1,795268 & 2 & 9 \\
\hline Average & 5,433333 & 5,044907 & 5,82176 & 90 & 1,854542 & 2 & 9 \\
\hline
\end{tabular}

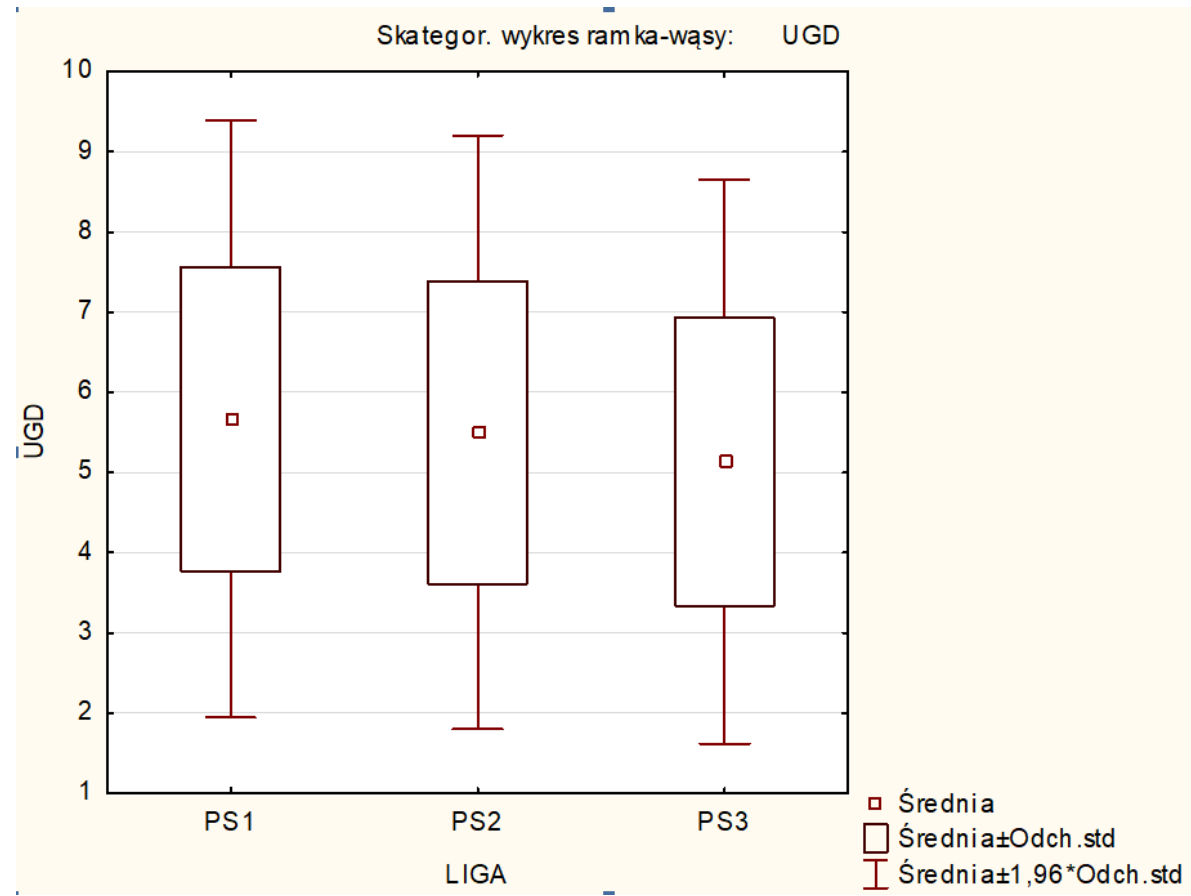

Fig. 4. Diagram for the variable agreeableness of the three examined groups of volleyball players. 


\section{Conscientiousness (SUM)}

Basic descriptive data on the conscientiousness scale are summarized in Table 7 and illustrated in Figure 5. A statistically significant difference in the conscientiousness scale occurred between the players of the first and third league of indoor volleyball (Table 8).

Tab. 7. A list of basic descriptive statistics of the variable conscientiousness of the three groups of volleyball players under study.

\begin{tabular}{|c|c|c|c|c|c|c|c|}
\hline LEAGUE & $\begin{array}{c}\text { UGD } \\
\text { Average }\end{array}$ & $\begin{array}{c}\text { Trust } \\
\mathbf{9 5 , 0 0 \%}\end{array}$ & $\begin{array}{c}\text { Trust } \\
\mathbf{+ 9 5 , 0 0 \%}\end{array}$ & $\begin{array}{c}\text { UGD } \\
\text { Important }\end{array}$ & $\begin{array}{c}\text { UGD Standard } \\
\text { deviation }\end{array}$ & $\begin{array}{c}\text { UGD } \\
\text { Min }\end{array}$ & $\begin{array}{c}\text { UGD } \\
\text { Maks }\end{array}$ \\
\hline PS1 & 7,466667 & 6,959648 & 7,973685 & 30 & 1,357821 & 5 & 10 \\
\hline PS2 & 6,7 & 6,019551 & 7,380449 & 30 & 1,822276 & 3 & 10 \\
\hline PS3 & 6,433333 & 5,847559 & 7,019107 & 30 & 1,568732 & 3 & 10 \\
\hline Average & 6,866667 & 6,523875 & 7,209458 & 90 & 1,636659 & 3 & 10 \\
\hline
\end{tabular}

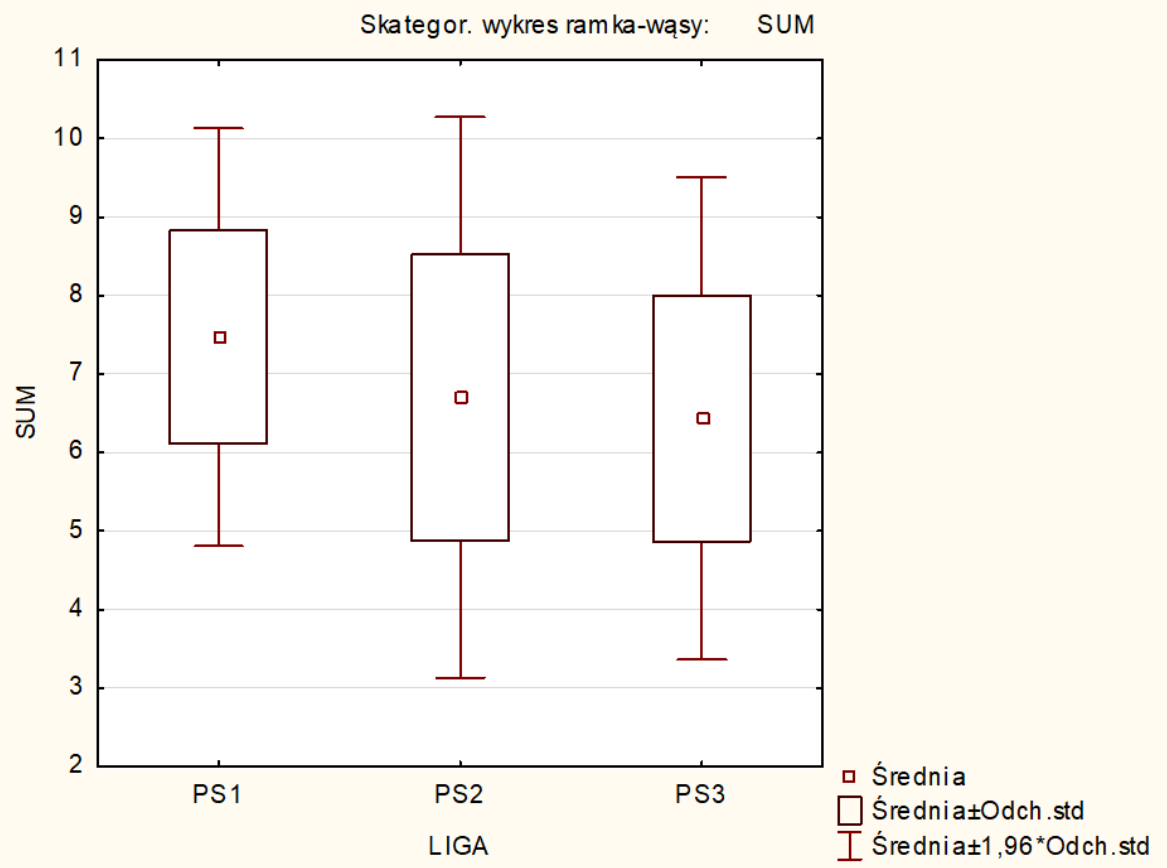

Fig. 5. Diagram for the variable conscientiousness of the three examined groups of volleyball players. 
Tab.8. Summary of the strength of differences in the conscientiousness scale between the examined groups.

\begin{tabular}{|c|c|c|c|}
\hline \multicolumn{4}{|c|}{ Tuckey's RIR test; variable: SUM; Significance at the level $\mathbf{p}<\mathbf{0 , 0 5}$} \\
\hline & $\{\mathbf{1}\}-\mathbf{M}=\mathbf{7 , 4 6 6 7}$ & $\{\mathbf{2}\}-\mathbf{M}=\mathbf{6 , 7 0 0 0}$ & $\{\mathbf{3}\}-\mathbf{M = 6 , 4 3 3 3}$ \\
\hline PS1 $\{\mathbf{1}\}$ & & 0,155916 & 0,036790 \\
\hline PS2 $\{\mathbf{2}\}$ & 0,155916 & & 0,794177 \\
\hline PS3 $\{\mathbf{3}\}$ & 0,036790 & 0,794177 & \\
\hline
\end{tabular}

\section{Conclusions}

The conducted research shows that there are statistical significant differences between volleyballers from the first and third league of indoor volleyball in terms of neuroticism, extraversion and conscientiousness. In terms of neuroticism, the former have a significantly lower scale than the latter. This confirms that players who take part in the third division are more susceptible to stressful situations, have less control over their ambitions and their goals are much more abstract.

In the case of extraversion, first league players have a noticeably statistically significant difference in relation to volleyballers from the third league. Their rate was definitely the highest. This means that this group is characterized by the greatest optimism, is the friendliest and feels positives from the world.

The last significant statistical difference between the examined groups is diligence. The first league reached the highest rate on this scale. This shows that these players are characterized by greater punctuality, willpower and motivation to act, they are more professional in what they do than volleyballers from the third league.

Noticeable changes in the above planes may be caused by the fact that the first league is a professional and professional league. Players are subject to club agreements and monthly settlements. However, the third league is an amateur league, which, apart from the possibility of practicing this discipline, does not bring any profit to the player and the player is not associated with the club by any contract. In the case of openness to experience and agreeableness, there were no significant differences between the subjects. This means that the intensification of features in the scales of openness to experience and agreeableness is at a similar level in the examined players from three levels of indoor volleyball.

\section{References}

Costa Jr P., McCrae R. (2007) Inwentarz Osobowości NEO-FFI. Warszawa: Pracownia Testów Psychologicznych. Adaptacja polska: B. Zawadzki, J. Strelau, P. Szczepaniak, M. Śliwińska.

FEPSAC (Fédération Européenne de Psychologie des Sports et des Activités Corporelles) European Federation of Sport Psychology (2015) Statutes. Brussels: Establishment of an International Non Profit Association (INPA).

McCrae R, Costa Jr. P. (2003) Personality in Adulthood: A Five-Factor theory perspective. New York: Guilford Press. 
Piepiora P. (2015) Reaktywność emocjonalna zawodników karate startujących w odmiennych systemach walki sportowej kumite. Roczniki Naukowe Wyższej Szkoły Wychowania Fizycznego i Turystyki w Białymstoku, 3 (13), 46-51.

Piepiora P. (2019) Behaviors of Professional Athletes in Terms of The Big Five Model Due to the Type of Contact of the Sport Discipline [W:] 14th International RAIS Conference on Social Sciences and Humanities at Princeton, The Erdman Center, 20 Library Place, Princeton, NJ 08540, USA, August 1920, 138-145;

Piepiora P., Cięszczyk I., Krzesiński M. (2017a) Young athlete personality model using the example of selected sport disciplines. Roczniki Naukowe Wyższej Szkoty Wychowania Fizycznego i Turystyki w Białymstoku, 4 (22), 5-13.

Piepiora P., Cięszczyk I., Krzesiński M. (2017b) Wizerunek a agresywność młodych sportowców na przykładzie wybranych dyscyplin sportowych. Roczniki Naukowe Wyższej Szkoły Wychowania Fizycznego $i$ Turystyki $w$ Biatymstoku, 1 (19), 45-51.

Piepiora P., Cięszczyk I., Krzesiński M. (2018a) Różnice w temperamencie wśród młodzieżowych zawodników trenujących sport indywidualny i zespołowy. Roczniki Naukowe Wyższej Szkoły Wychowania Fizycznego i Turystyki w Bialymstoku, 3 (25), 44-50.

Piepiora P., Jagoda A., Urban J. (2019a) Physical activity and styles of coping with the stress of people aged 18-30. Journal of Education, Health and Sport, 9 (7), 36-40.

Piepiora P., Kwieciński A., Migasiewicz J. (2019b) The impact of the level of focus on a change in the level of fear of falling during leading in competition climbing. Journal of Education, Health and Sport, 9 (5), 516-533.

Piepiora P., Migasiewicz J., Napieraj D. (2019c) Personality profile of athletes practising endurance disciplines. Journal of Education, Health and Sport, 9 (4), 394-402.

Piepiora P., Piepiora D., Witkowski K. (2016a) Personality of the karatekas and kumite sport fight systems (in view of the karate culture as the regulator of this interdependence). Journal of Combat Sports and Martial Arts, 7 (1), 3541.

Piepiora P., Piepiora Z. (2015) The karate culture as the regulator of interdependence between permitted level of violence in different kumite systems and personality of contestants. Human And Social Sciences at the Common Conference (HASSACC), 3 (1), 23-27.

Piepiora P., Superson M., Migasiewicz J. (2019d) Personality and subjective assessment of body weight of tennis players. Journal of Education, Health and Sport, 9 (6), 394-397.

Piepiora P., Superson M., Witkowski K. (2017c) Osobowość a masa ciała i poziom tkanki tłuszczowej na przykładzie zawodniczek piłki siatkowej. Roczniki Naukowe Wyższej Szkoły Wychowania Fizycznego $i$ Turystyki $w$ Biatymstoku, 2 (20), 52-55.

Piepiora P., Superson M., Witkowski K. (2017d) Personality and the body composition of athletes using the example of the Polish national youth 
female wrestling team. Journal of Combat Sports and Martial Arts, 8 (2), 107-109.

Piepiora P., Superson M., Witkowski K. (2017e) Personality and the nutritional habits of athletes using the example of the Polish national youth female wrestling team. Archives of Budo: Science of Martial Arts and Extreme Sports, 13, 103-110.

Piepiora P., Supiński J., Witkowski K. (2015) The temperament of karate competitors versus the systems of kumite sports fight. Journal of Combat Sports and Martial Arts, 6 (2), 49-52.

Piepiora P., Szmajke A., Migasiewicz J., Witkowski K. (2016b) The karate culture and aggressiveness in kumite competitors. Ido: Movement for Culture: Journal of Martial Arts Anthropology, 16 (2), 41-47.

Piepiora P., Witkowski K. (2018) Personality traits of competitive athletes according to type of pressure exerted on opponents. South African Journal for Research in Sport, Physical Education and Recreation, 40 (1), 97-109;

Piepiora P., Witkowski K., Piepiora Z. (2018b) Personality profiles of karate masters practising different kumite styles. Archives of Budo, 14, 231-241.

Wiggins J. (1996) The Five-Factor model of personality. New York: Guildford Press. 